\title{
THE LEXICAL BORROWING IN PALESTINIAN COLLOQUIAL ARABIC
}

\author{
Nael F. M. Hijjo ${ }^{1}$ \\ Mahmoud S. S. Fannouna ${ }^{2}$ \\ ${ }^{1}$ Faculty of Languages and Linguistics, University of Malaya \\ ${ }^{2}$ Faculty of Humanities, Universiti Sains Malaysia \\ 1nael_hijjo@yahoo.com \\ 2mahmoud_msf@hotmail.com
}

\begin{abstract}
The paper aimed to determine the social factors responsible for the variable use of [g], [k] and the prestigious [?] in the Colloquial Arabic of the Gaza Strip women. These variables are of interest because they each have one variant that coincides with al-Fussha Arabic; which is the standard /q/. Towards this end, a quantitative study was carried out to examine the frequency of each sound in the naturally occurring speech of a sample of eight female participants belonging to families, six of whom have migrated from the occupied Palestine in year of 1948 and the other two are citizens of the Gaza Strip, where $[\mathrm{g}]$ is socially dominant, to the Gaza city. The findings suggest that younger generation shift from $[\mathrm{g}]$ or [kshift to the prestigious form [?] to show prestige in the society. Thus the variable use of the original sound [g] in Gaza city could be a language shift.
\end{abstract}

Keywords: colloquial Arabic, variation, lexical borrowing, language shift

\section{Introduction}

The relation between sound change and social factors has been investigated by many researchers, particularly Labov (1972), who inspired many analysts to carry out studies implementing his techniques. These kinds of studies are usually conducted to discover whether language variation could potentially cause a major change in a language. The three sounds, glottal stop [?], the voiced velar plosive [g] or to the voiceless velar plosive [k], are variations to al-Fussha الفصحى (the Standard Arabic) sound /q/, the voiceless uvular stop. However, the less frequent words in colloquial Arabic are usually technical and specialised terms used for specific purposes (Habib, 2005; Holes, 2004, 1995). Their production of the new prestigious form [?] may be delayed or impaired. It is also expected that highly frequent words with the [?] sound are acquired faster by speakers whose speech is variable (Medoza-Denton, Hay, \& Jannedy, 2003; Pierrehumbert, 2001). The effect of word frequency on the acquisition process of urban prestigious forms within the framework of sociolinguistic variation is not widely studied, particularly in relation to Arabic language (Habib, 2010). 
According to Abuamsha (2010), in the Gaza Strip, the uvular voiceless plosive / $q$ / becomes a glottal stop / $/$ / when pronounced by urban speakers in the city of Gaza. These speakers who live in the city are usually of an urban origin; however, other speakers may be of a rural origin and have moved to live in the city and adopted its dialect. Other Palestinian speakers may be of an urban origin and yet they live in countryside or one of the refugee camps in different parts of the Gaza Strip and they still retain their urban dialect (Abuamsha, 2010).

The study aimed to determine the effectual social factors on the Gaza Strip women's choice of using [?] rather than [g] or [k] as a frequent variant that coincides with al-Fussha Arabic /q/.

\section{Literature Review}

Many sociolinguistic studies have discussed sound change in correlation with social factors such as sex, age, occupation and social class (e.g., Daher 1998a, 1998b, 1999; Haeri, 1991, 1992, 1996; Labov, 1966, 1972). The significance of social stratification in the ranking of the individual's use of a certain sound has been emphasised by Labov $(1963,1966)$ and adapted by many other scholars, such as Haeri (1991, 1992, 1996) and Daher (1998a, 1998b, 1999). Similarly, Hurreiz (1978) figured out the influence of social stratification on linguistic variation. For Habib (2005), age, sex, education, and work setting are the major social factors lead to the sound change.

Many studies on sound variations focus on the $[r]$ and [r-less] use The "English postvocalic / $r$ / has been the most researched sound in dialect formation" (Burling, 1973, p. 16). The variability of the phonetic features of $/ r /$ phoneme across the USA and the UK was shown by a number of researchers including Labov (1966), Burling (1973), Rickford (1996) and Rogers (2000). The target of these studies was to form a clear picture of the variations of the sound / $r$ / across regions supported by dialect maps for both the US and UK. Labov (1966) provided a detailed illustration of the post-vocalic $/ r /$ in the New York City. He investigated a number of socially stratified areas that represent the socio-linguistic variables. Labov's approach confirms that even though the speech of the informants appeared to be arbitrary; it is regionally stratified. Even English used in the USA and the English used in the UK have differences though they are mutually comprehensible. This is in contrast with Arabic wherey there is occasional misunderstanding between speakers of the Arabic dialects spoken in the urban and the rural regions as explained later in this paper.

Arabic dialect studies covered various dialectical topics, mainly phonological variation. Ferguson (1959) wrote the first classic article on diglossia in the Arab world which distinguished between High Arabic and Low Arabic. Two different forms of Arabic exist side by side: Modern Standard Arabic (MSA) and Colloquial Arabic, "The Vernacular". MSA corresponds to the High Variety, which is used as a vehicle for "Highly Codified" literature and is learnt at school. Nevertheless, colloquial Arabic corresponds to the Low Variety which is used in everyday casual speech. Ferguson (1959) attributed diglossia to the early development of Arabic whereas the Standard has remained established or unchanged because the high variety relies upon the Holy Qur'aan. 
Ferguson (1959) showed that the High Variety is considered as more superior than the Low Variety. The superiority of the High Variety is attributed to the Holy Qur'aan and "as such is widely believed to constitute the actual words of God and even to be outside the limits of space and time" (p. 237). Therefore, the High Variety is learnt consciously through formal education, yet the low variety is acquired spontaneously which contains the daily life conversation of the public (AlFaqeih, 2010). Ferguson (1959) argued that many regional dialects exist in various Arab countries, withvariations in grammar, lexicon, phonology, function, prestige, literary heritage, acquisition, standardisation, and stability.

Various sociolinguistic studies have shown a strong correlation between language and social structure, which means that "social variation is mirrored in language" and that the main function of dialectical variations in a society is to "provide information to the listener about the speaker" (Williams, 1992, pp. 66-67). Moreover, the identification of the social construction and the common knowledge between the speaker and the recipient leads to understanding or misunderstanding of the message (Nimer, 2006).

Furthermore, Blanc (1953) studied the Arabic spoken by the Druze of Western Galilee and Mount Carmel in the North of Palestine. He investigated the consonants, vowels, prosodic features and other aspects of this variety. His study considered religion as a decisive factor for the dialectical variations of the Druze, Muslims, and Christians. The researcher attempted to collect realistic and reliable data from his informants through recording words, stories or whatever is said and transcribed them. Accordingly, he had many convincing results concerning the sociolinguistic varieties among the Druze. He found out that the [q] sounds are distinguishing features of the "north Palestinian rural dialects from their central Palestinian counterpart" (pp. 67-68).

However, there are always constraints that govern the surface variations of the language. Broselow (1992) and Abu-Mansour (1992) argued that all Arabic dialects share underlying phonological representations. Broselow (1992) compared the surface and deep structure of the investigated dialects (Cairene, Makkan, Iraqi, Sudanese, and Syrian) and concluded that even though these dialects exhibit variations they share underlying structural similarities. Similarly, Atawneh (2003) found out that epenthesis in the Hebron dialect differs from other dialects showing that phonological constraints allow it to happen. Hebron dialect is like any other Palestinian dialect where epenthesis is needed in certain contexts.

Investigating the dialects spoken in Jordan, Suleiman (2004) discussed that the interdialect variation of the $/ q /$ sound is a product of politics and conflict due to the Palestinian existence in Jordan after the 1967 Arab-Israeli war. Consequently, Abdel Jawad (1981) examined the sociopolitical structure of the existing dialects in Jordan based on gender, attitudes and style. He insisted that the dialect variants of /q/: ([?] Madani), ([k] Fallahi) and ([g] Bedouin) reflect different social communities in Jordan, and code-switching may occur among these variants depending on the attitude towards the dialect feature and gender.

In Palestine, which is very similar to the Jordanian situation, the variants which discussed by Abdel Jawad (1981) have the same distribution. The Palestinian dialects were affected by many foreign factors through language contact throughout 
the history of living under the rule of Roman Empire, Byzantines, Crusaders, Muslim Empire, Ottomans and the British Mandate. Many foreign phonetic features were brought in throughout these. Ahmad (2000) stated that linguistic borrowing is a natural phenomenon in many languages. Therefore, the Palestinian dialects borrowed some features (especially some lexis) of the languages of the nations that controlled Palestine over the ages.

Yet, some other linguists studied the factors that lead to dialect formation across regions. Aniis (1973) and Hilaal (1990) stated that dialect formation is mainly due to four factors:

1- The contact between nations for political reasons such as invasion, and migration.

2- Social reasons such as common way of life and traditions.

3- Geographical typography such as rivers, plains, low land and high land.

4- Linguistic conflict as a result of immigration or invasion.

Another study by Faakhir (1983) showed geographical factor as a decisive factor of dialect formation. He investigated this factor by introducing the relation between the dialects that existed in Saudi Arabia and the surrounding dialects as related to the Qatari Dialect. He argued that this relation is traced back to the 17th century because of some environmental factors (e.g., draught), the spread of the tribes across a wide geographical area, resulting in the appearance of many dialects. He explained that the dialects of Qatar kept the features of Modern Standard Arabic since this dialect did not come into contact with other regions which happened, for instance, in Iraq, Morocco, Egypt, Palestine and Syria. However, the Levantine Dialects were in contact with and affected by the Turkish language especially the Northern part in addition to the Syrianic and Hebrew languages that existed in Syria and Palestine.

\section{Sound variation in dialect formation}

This section provides illustrations and explanations of the existence of the variants of the / $q$ / sound which has been extensively investigated by Arab linguists. Some aspects of the Palestinian dialects have been shortly studied. Recent research has begun to focus on sound variations motivated by social and geographical factors. Aspects of language as morphology, semantics and syntax have been covered more than phonology of the sociolinguistic structure of the community. Blanc (1953), Anis (1973), and Ahmad (2000) have discussed the Arabic dialects in general including the Palestinian dialects. For instance, Anis (1973) investigated the history of the Arabic dialects, and he found some signs of the tribal dialects in the various areas. He emphasized that most of the available studies about dialects of early tribes were brought to us either through the Holy Qur'aan or poetry. Further, exploring the variants that govern the $/ q /$ distribution is meant to find explanations for such variations which will enhance the understanding of the phonological processes related to these key sounds in dialect formation.

The phonological phenomenon of 'Sound Substitution is an ever present phenomenon in human language. At this time, the variants of the sounds /q/ have 
features that distinguish between the rural and urban regions as it appears in Palestine.

Abdel-Jawad (1981) investigated the use of [q] in a stratified sample of Amman in Jordan. He explained how the [q] has merged with either [k], [g], or [?] through the years: $[\mathrm{g}]$ in the Nomad dialect, [k] in the rural dialect, and [?] in the urban dialects. He presents (q) as a sociolinguistic variable related to sex, social class, and urban/rural origins.

One of the main phonological features that distinguish the Palestinian main spoken dialects in different regions of the country is the pronunciation of the standard voiceless uvular plosive [q] or "qaaf". Rural Palestinian speakers in the countryside are generally distinguished by pronouncing qaaf " $q$ " as a voiceless velar $\mathrm{kaf} / \mathrm{k} /$ which distinguishes them from other Arabic varieties. Palestinian speakers of urban dialects in most cities, on the other hand, render the "qaaf" as a glottal stop $/ \mathrm{R} /$ which is much more similar to the northern Levantine dialects of Syria and Lebanon. Also the [qaaf] becomes the voiced velar /g/ when rendered by rural or Bedouin speakers in the far South of Palestinian territories including the Gaza Strip (Abuamsha, 2010).

\section{Methodology}

\section{Research site}

The Gaza Strip is the southern part of Palestinian territories (see Appendix A for map). It is a narrow piece of land along the Mediterranean coast between Lebanon and Egypt - about $40 \mathrm{~km}$ long and $10 \mathrm{~km}$ wide with an area of only 360 square kilometres. The Gaza Strip is home to more than 1.7 million Palestinians and the majority of its population are refugees who represent over three-quarters of the current estimated population. According to UNRWA (2010), the total number of Palestinian refugees in Gaza is 1,073,303, of which 495,006 of them are living in eight refugee camps in different parts of the Gaza Strip from its north to south.

The participants came from five residential areas in the Gaza Strip: Gaza city, Khanyounis, Rafah, Deir-Al-Balah and Nusierat. Gaza city is a central residential area in the Gaza Strip which carries its own traditional values. It is believed by other inhabitants that people who live in Gaza city are upper-class; thus as a residential area, it is imbued with prestige. On the other hand, Khanyounis is also a historical city and adjacent refugee camp in the southern part of the Gaza Strip. Rafah, DeirAl-Balah and Nusierat are newly developing residential areas which grew more than fifty years ago and is mainly occupied by migrants from rural areas after the 1948. Therefore, the five areas differ with respect to their history.

The tradition and prestige associated with Gaza Strip is expected to have a great influence on the newcomers, especially since the majority of the residents are citizens. This influence might be minor in other regions, since the majority of the residents are not originally Gaza people and have moved in recently. Education and occupation may also affect the person's social class with time. For example, if one is a medical doctor or an engineer who comes from a poor family, his/her social status 
may change with time as s/he starts to be more known and to make more money; this might be referred to as social mobility (Haeri, 1991, 1996).

\section{Participant}

Most of the participants were from the Gaza city where [?] is used in the Colloquial speech. Almost all of the participants were the daughters of the migrants from the occupied Palestine original place of residence after the year of 1948. They were considered as refugees. We were personally acquainted with most of the participants, who were not picked at random. Thus the sample here is a nonprobability purposive that serves the aims of the current study. All participants were university students from five different places of residence in the Gaza Strip chosen according to the population concentration starting from Gaza city moving to Khanyounis, Rafah, Deir-Al-Balah and Nusierat. See Table 1 for place of residence of the eight participants.

Table 1.

Background information of the research participants.

\begin{tabular}{ccc}
\hline Participant & Place of Residence & Citizenship \\
\hline 1 & Khanyounis & Citizen \\
2 & Nusierat & Refugee \\
3 & Gaza City & Citizen \\
4 & Deir-Al-Balah & Refugee \\
5 & Gaza City & Refugee \\
6 & Gaza City & Refugee \\
7 & Khanyounis & Citizen \\
8 & Rafah & Refugee \\
\hline
\end{tabular}

\section{Instrument}

The dependent or linguistic variable of the present study is the Standard Arabic sound (q), which appears in the speech of the Gaza Strip community as three variants: [g], [k] and [?]. There is no specific phonological context in which [?] occurs as a replacement for [q]. It can occur in many phonological contexts except in certain lexical borrowings from Standard Arabic (SA), such as [qur?aan] Qur'an, [liqaa?] meeting, and [Oaqaafe] cultural. For example, [qalem] pen, [raqbi] neck, and [wareq] paper become [?alam], [rapbi], and [wara?] respectively. These examples show that the change could occur word-initially, word-internally, and word-finally.

The independent or extralinguistic variables included in the quantitative analysis are the following:

1- Citizenship (Citizen/Refugee)

2- Place of Residence. 
The instrument of gathering the data is a questionnaire that consists of two sections. Section A of the questionnaire gathered some participants' specific background which comprised two items (citizenship and place of residence). Section B comprised eight items which measured the variants used of the Standard / $q /$ in different situations. There were seven items designed in a selected-response format where respondents had to circle one response. Selected-response or forced-choice item was used because it enhances consistency of response across respondents while making data tabulation straightforward and less time consuming. One item was an open-ended question to supplement and verify the questionnaire data.

The Arabic translation of each item was written after the English version. A pilot study of items was undertaken on a group of three students who were not selected for the actual study. The students involved in the pre-test resembled the sample participants of the study since they were from the same surrounding region; one participant was a refugee residing in Gaza city but the other two participants reside in Khanyounis where one is a refugee and the other is a citizen. The students wereuniversity students at Al-Azhar University-Gaza. The purpose of this pilot test was to identify any ambiguous items and to find any inconsistency in students' responses. The items were modified according to students' responses.

\section{Data collection and analysis procedures}

To investigate the use of the three different variants, questionnaires were distributed to eight female university students residing in the Gaza Strip. The collection of data took place throughout the internet. The Head of the Department of English-French Literature at Al-Azhar University in Gaza city, Dr Ihab Abu-Mallouh, made arrangements to facilitate collection of data, whichever was more convenient at the time. After collecting all the data from the participants, the researchers calculated the number of occurrences of [g], [k] and [?] in the speech of each participant to examine the possible significance of each of the social factors (see Table 2).

\section{Results and Discussion}

\section{Distribution of variants of Standard Arabic /q/}

The data analysis showed that the variant [?] dominated in the place of residence of participants $1,2,3,5$ and 6 while the variant [g] was used by participants 4 and 7 , and participant 8 used the variant [k] (Table 2). In the family, Participants 1, 2 and 3 used the variant [?] with their family in everyday interactions whereas participants 4, 5, 6, 7 and 8 used the variant [g]. Participants 1, 2, 3 and 6 used the variant [?] when they engaged in conversations with visitors in their place of residence, meanwhile participants $4,5,7$ and 8 utilised the variant [g]. When interacting with university colleagues, participants 1, 2, 3, 6 and 7 used the variant [?] but not in the case of participant 4,5 and 8 who used the variant [g]. None of thepParticipants utilise more than one variant except for the case of participants 6 and 7 who used the variants [g] and [?]. The family of participant 4 used the variant 
[g] only, the family of participant 8 used the variant [k] only but all other participants' family used the variants [g] and [?]. In the open ended question, participants 1, 2, 3 and 4, used only one variant in their speech but the participant 5 , 6,7 and 8 utilised more than one variant.

Table 2.

The distribution of the variants of Standard Arabic $/ q /$ in different situations.

\begin{tabular}{|c|c|c|c|c|c|c|c|c|}
\hline Social situation & P1 & $\mathbf{P 2}$ & P3 & P4 & P5 & P6 & P7 & P8 \\
\hline $\begin{array}{l}\text { Q1: In place of } \\
\text { residence }\end{array}$ & [?] & [?] & [?] & {$[\mathrm{g}]$} & [?] & [?] & {$[\mathrm{g}]$} & [k] \\
\hline Q2: with family & [?] & [?] & [?] & [g] & [g] & {$[\mathrm{g}]$} & {$[\mathrm{g}]$} & [g] \\
\hline $\begin{array}{l}\text { Q3: with visitors in } \\
\text { place of residence }\end{array}$ & [?] & [?] & [?] & {$[g]$} & [g] & [?] & {$[g]$} & [g] \\
\hline $\begin{array}{l}\text { Q4: with colleagues in } \\
\text { university }\end{array}$ & [?] & [?] & [?] & [g] & [g] & [?] & [?] & [g] \\
\hline Q5: with friends & [?] & [?] & [?] & [g] & [g] & [?] & [?] & [g] \\
\hline $\begin{array}{l}\text { Q6: variants used by } \\
\text { participant }\end{array}$ & - & - & - & - & - & $\begin{array}{c}{[\mathrm{g}]} \\
\text { and } \\
{[?]}\end{array}$ & $\begin{array}{c}{[\mathrm{g}]} \\
\text { and } \\
{[\mathrm{P}]}\end{array}$ & - \\
\hline $\begin{array}{l}\text { Q7: variants used by } \\
\text { participant's family }\end{array}$ & $\begin{array}{c}\text { [g] } \\
\text { and } \\
{[\mathrm{P}]}\end{array}$ & $\begin{array}{l}{[\mathrm{g}]} \\
\text { and } \\
{[?]}\end{array}$ & $\begin{array}{l}{[\mathrm{g}]} \\
\text { and } \\
{[?]}\end{array}$ & [g] & $\begin{array}{l}\text { [g] } \\
\text { and } \\
{[?]}\end{array}$ & $\begin{array}{l}\text { [g] } \\
\text { and } \\
{[?]}\end{array}$ & $\begin{array}{c}{[\mathrm{g}]} \\
\text { and } \\
{[?]}\end{array}$ & [k] \\
\hline
\end{tabular}

\section{Influence of citizenship background and place of residence on use of variants of Standard Arabic / q/}

Citizenship background and place of residence play a significant role in the change of the Standard Arabic [q] to [g], [k] or [?] (Table 2). Participants 1, 2 and 3 used the variant [?] in almost all of the social situations, though some of their family members use the variant $[\mathrm{g}]$, which means they have shifted completely with no regards to any other variant to the [?] variant. What is worth mentioning is that P1 and $\mathrm{P} 3$ were both citizens whereas $\mathrm{P} 2$ was a refugee, Participants 1,2 and 3 resided in different places; Khanyounis, Nusierat and Gaza city respectively. However, P4 used the variant $[\mathrm{g}]$ only, as the place of residence was dominated by this variant. P4 and her family were refugees who used this particular variant in everyday life. P5's place of residence was dominated by the [?] variant; yet, she still used the variant [g]. Unlike P8 who was a refugee and resided in Rafah, she used the variant $[\mathrm{g}]$, though the place of residence and family members' speech were dominated by the variant [k]. It is obvious from Table 2 that participants $1,2,3,4,5$ and 8 used only one particular variant unlike participants 6 and 7 who use two different variants according to the social situation. Participant 6 was a refugee residing in the Gaza city. Although herplace of residence was dominated by the variant [?], she used the [g] sound with her family members who also used the same variant but she shifted to the variant [?] in the other situations. Participant 7 was a citizen residing in 
Khanyounis where the variant [g] dominated, but the variant [?] was used only within the university atmosphere and with friends but she shifted to [g] with her family members and visitors. An exceptional case is that Participants 4 and 8 did not use the variant [?] in all social situations, whereas the other participants tended to use the [?] variant whether to accommodate their speech with the surrounding community or as a prestigious marker. Participants 1, 2, 3, 5 and 6 resided in a dominated [?] variant; Khanyounis, Nusierat, Gaza city, Gaza city and Gaza city in respect to the place of residence. It is also noticed that participants 1 and 7 both are citizens who reside in the same city but each of their living places were dominated by different variants - for P77, it wasthe variant [g] and for P1it was the [?] variant. P6 and P7 explained that they used the [g] variant to cope with the surrounding area, and the use of [?] variant gives the impression of prestige among the community. All participants presented a pragmatic justification for the use of a particular variant, which is to adapt to the surrounding area, to ensure a better communication with the majority of the people, and to avoid discrimination or negative attitudes. This justification was mentioned by participants complained of having been the target of jokes because of using the variants $[\mathrm{g}]$ and [k] as the university is located in the Gaza city that is dominated by the [?] variant.

However, if one does not have the necessary motivation or desire to accommodate a different form in speech, social integration may be greatly hindered. Such tendencies are evident among migrant speakers in the Gaza Strip: some have lived for years in the city and have never adopted the new form since they do not have the desire to adopt a new identity. On the other hand, some people choose to be identified as urban, and strive to adapt their speech.

\section{Conclusion}

The usage of the [g], [k] and [?] variants of Standard Arabic in the Gaza Strip differ from one speaker to another, bringing to mind Giles, Coupland and Coupland's (1991) idea that not all speakers can simply imitate in the same way any variety they encounter. Labov (1972) argued that "women are usually initiators of linguistic change (p. 243). According to Giles et al.'s (1991) theory of speech accommodation, people tend either to converge when they wish to decrease the social distance among each other, i.e. use the same style of speaking, or to diverge when they wish to increase that social distance and distinguish themselves from other speakers, i.e. use a different style of speaking. This also corresponds with the view of Habib (2005) that [?] has more social prestige than [g] among women. It has been demonstrated that place of residence plays the major role in the change from [g] to [?] in the Gaza Strip. These are indications that a change in Palestinian Arabic is in the progress.

The emphasis on the Arabic roots and the Quran as a basis for the Arabic language may prevent the occurrence of complete merger of [g] and [?] or the extension of this merger to SA. The great stylistic and social variation that prevails in the Gaza Strip reflects a consistent pattern. 


\section{References}

Abuamsha, D. (2010). Terms of address in Palestinian Arabic. Muncie, Indiana: Ball State University.

Abdel-Jawad, H. (1981). Language and society: Cross-dialectical variation in Arabic: Competing prestigious forms. Cambridge: Cambridge University Press.

Abu-Mansour, M. (1992). Vowel shortening in two Arabic dialects. In E. Broselow \& M. Eid \& J. McCarthy (Eds.), Perspectives on Arabic linguistics IV: Papers from the Fourth Annual Symposium on Arabic Linguistics. Amsterdam/Philadelphia: John Benjamin Publishing Company.

Ahmad, A. (2000). Flashes on some phonetic phenomena in the Palestinian dialects and their relationship with old Arabic dialects. Humanistic Science Magazine. 13(2), 56-73.

Anis, I. (1973). In Arabic Dialects ( $2^{\text {nd }}$ ed.). Cairo: The Egyptian Anglo Library.

Atawneh, A. (2003). Epenthesis in the Futha and Hebron Dialect of Palestinian Arabic. Bethlehem University Journal.

Blanc, H. (1953). Studies in North Palestinian Arabic. Linguistic inquiries among the Druze of Western Galilee and MT. Carmel. Unpublished PhD Dissertation, The Israel Society Oriental, Jerusalem.

Broselow, E. (1992). Parametric variation in Arabic dialect phonology. In E. Broselow \& M. Eid \& J. McCarthy (Eds.), Perspectives on Arabic linguistics IV: Papers from the Fourth Annual Symposium on Arabic Linguistics (pp. 7-46). Amsterdam/Philadelphia: John Benjamin Publishing Company.

Burling, R. (1973). English in Black and White. New York: Holt, Rinehart and Winston, Inc.

Daher, J. (1998a). Linguistic variation in Damascus Arabic: A quantitative analysis of men's and women's speech. Unpublished PhD dissertation, New York University.

Daher, J. (1998b). Gender in linguistic variation: The variable (q) in Damascus Arabic. In E. Benmamoun, M. Eid \& J. McCarthy (Eds.), Perspectives on Arabic linguistics XI: Papers from the Eleventh Annual Symposium on Arabic Linguistics (pp. 183-206). Amsterdam: John Benjamins.

Ferguson, C. (1959). Diglossia. Word - Journal of the International Linguistic Association, 15, 325-340.

Giles, H., \& Coupland, N., \& Coupland. J. (1991). Accommodation Theory: Communication, context and consequence. In H. Giles, J. Coupland \& N. Coupland (Eds.), Contexts of accommodation: Developments in applied sociolinguistics (pp. 1-68). Cambridge: Cambridge University Press.

Habib, R. (2005). The role of social factors, lexical borrowing and speech accomodation in the variation of [g] and [?] in the Colloquial Arabic of Rural Migrant Families in Hims, Syria. Unpublished masters thesis, Sracuse University - USA.

Habib, R. (2010). Word frequency and the acquisition of the Arabic urban prestigious form [?]. Glossa, 5(2), 198-219. 
Haeri, N. (1991). Sociolinguistic variation in Cairene Arabic: Palatalization and the Qaf in the speech of men and women. Unpublished PhD dissertation, University of Pennsylvania.

Haeri, N. (1996). The sociolinguistic market of Cairo: Gender, class, and education. London: Kegan Paul International.

Labov, W. (1966). The social stratification of English in New York City. Washington DC: Center for Applied Linguistics.

Labov, W. (1972). Sociolinguistic patterns. Philadelphia: University of Pennsylvania Press.

Labov, W. (2001). Principles of linguistic change. Volume II: Social Factors. Oxford: Blackwell.

Nimer, O. (2006, November). Dialect and social indication. Paper presented at The Symposium of the Linguistic reality in Palestine, Al-Najah National University.

Rickford, R. J. (1996). Regional and social variations. I n S. L. M a cka y \& N. H. Hornberger ( $\mathrm{Eds}$.$) , Sociolinguistic and language$ teaching (pp. 151-194). Cambridge: Cambridge University Press.

Rogers, H. (2000). The sounds of language: An introduction to phonetics. New York: Pearson Education.

Suleiman, Y. (2004). A war of words: Language and conflict in the Middle East. Cambridge: Cambridge University Press.

The United Nations Relief and Works Agency for Palestine Refugees in the Near East [UNRWA], January (2010). West Bank \& Gaza Strip: Population and Census of (2007) report. Gaza: UNRWA .

Williams, G. (1992). Sociolinguistics: A sociological critique. Lo nd on: Routledge. 
Appendix A: Map of the investigated Palestinian areas in the Gaza Strip.

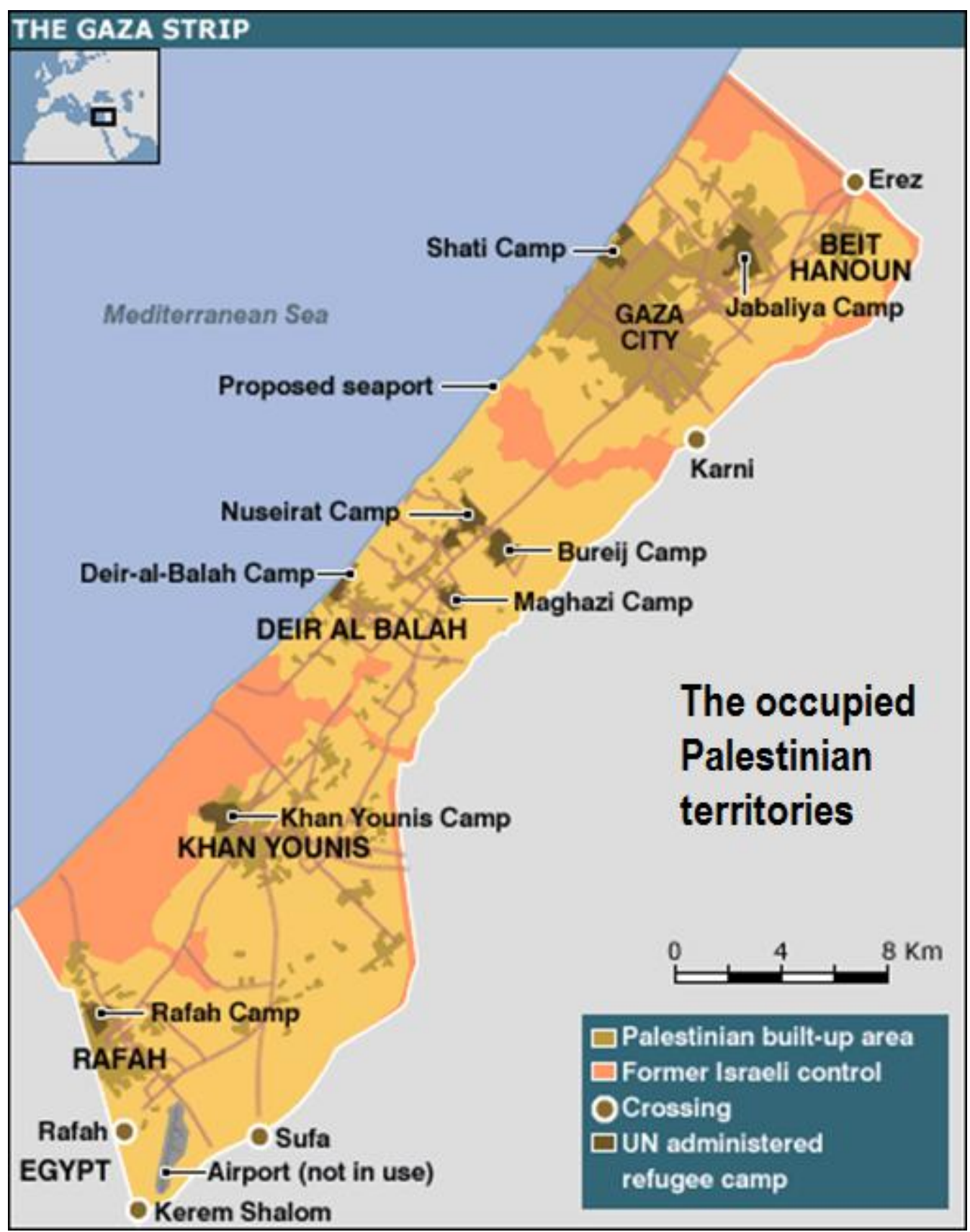


Appendix B: Questionnaire form used to elicit variants used by the participants This is where I describe the study and let people know that their participation is voluntary and that their data are anonymous and confidential.

\begin{tabular}{|c|c|}
\hline \multicolumn{2}{|c|}{$\begin{array}{c}\text { Questionnaire } \\
\text { إستبانة }\end{array}$} \\
\hline Section A & الجزء الأول \\
\hline $\begin{array}{l}\text { First l'd like to ask few questions about } \\
\text { yourself. }\end{array}$ & أولاً أود أن أسأكم بعض الأسئلة الخاصة بكم \\
\hline $\begin{array}{l}\text { 1- What is your place of } \\
\text { residence? }\end{array}$ & 1- ما هو مكان إقامتك؟ \\
\hline $\begin{array}{l}\text { 2- You are: } \square \text { a citizen } \\
\text { or } \quad \square \text { a refugee }\end{array}$ & 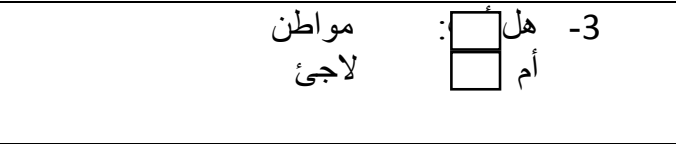 \\
\hline $\begin{array}{l}\text { Section B } \\
\text { There are many variants of speech in } \\
\text { Colloquial Arabic in the Gaza Strip, } \\
\text { some of these are [g], [k] or [?] for the } \\
\text { Standard Arabic sound qaaf [q]. } \\
\text { For example in Standard Arabic the } \\
\text { word /Qultu lak/ is used in the } \\
\text { colloquial Arabic in everday life, where } \\
\text { the different usages would be } \\
\text { /Poltellak/, /goltellak/, or /koltellak/. } \\
\text { Measure these examples on the use of } \\
\text { variants of the standard /q/ in different } \\
\text { situations according to the questions } \\
\text { below. }\end{array}$ & 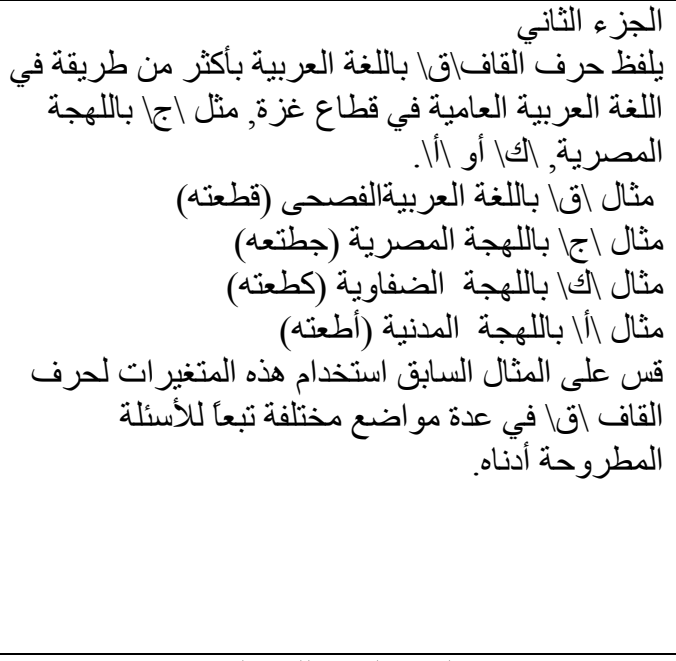 \\
\hline $\begin{array}{l}\text { 1. Is your place of residence } \\
\text { dominated by the variant }[\mathrm{g}] \text {, } \\
\text { [k] or }[\mathrm{P}] \text { ? } \\
\text { A- }[\mathrm{g}] \\
\text { B- }[\mathrm{k}] \\
\text { C- }[\mathrm{P}]\end{array}$ & 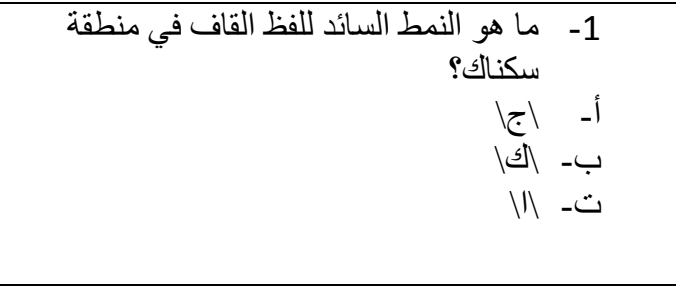 \\
\hline $\begin{array}{l}\text { 2. Which variant do you use when } \\
\text { you talk with your family } \\
\text { member? } \\
\text { A- }[\mathrm{g}] \\
\text { B- }[\mathrm{k}] \\
\text { C- }[\mathrm{P}]\end{array}$ & 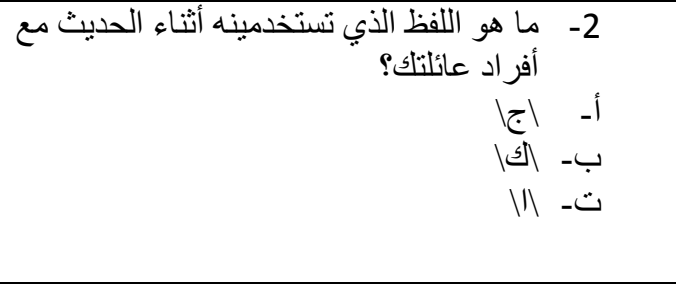 \\
\hline $\begin{array}{l}\text { 3. Which variant do you use in } \\
\text { your place of residence when } \\
\text { you talk with visitors? } \\
\text { D- }[\mathrm{g}] \\
\text { E- }[\mathrm{k}]\end{array}$ & 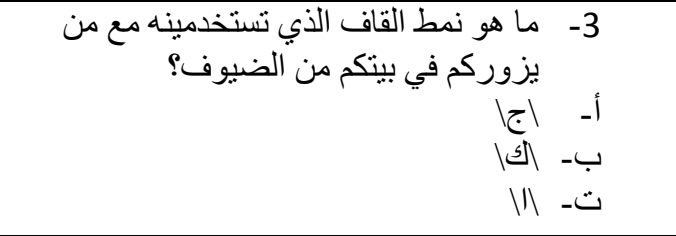 \\
\hline
\end{tabular}




\begin{tabular}{|c|c|c|}
\hline & F- [?] & \\
\hline 4. & $\begin{array}{l}\text { Which variant do you use at the } \\
\text { university when you talk with } \\
\text { your colleagues? } \\
\text { G- }[g] \\
\text { H- }[\mathrm{k}] \\
\text { I- }[\text { [?] }\end{array}$ & 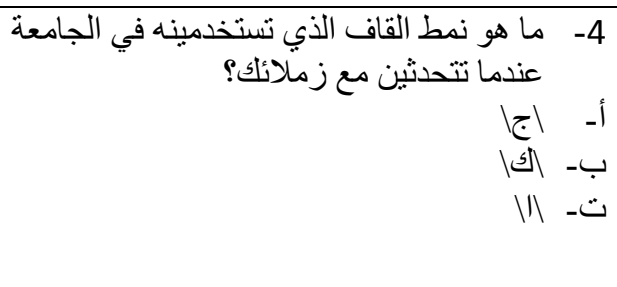 \\
\hline 5. & $\begin{array}{l}\text { Which variant do you use when } \\
\text { you talk with your friends? } \\
\text { J- }[g] \\
\text { K- }[\text { [k] } \\
\text { L- }[?]\end{array}$ & 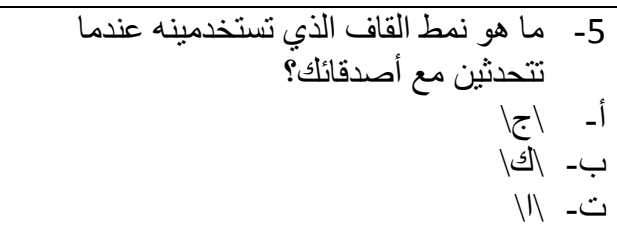 \\
\hline 6- & $\begin{array}{l}\text { If you use different variants, } \\
\text { what are they? } \\
\text { A- }[\mathrm{g}],[\mathrm{k}] \text { and }[\mathrm{?}] \\
\text { B- }[\mathrm{k}] \text { and }[\mathrm{g}] \\
\text { C- }[\mathrm{?}] \text { and }[\mathrm{g}] \\
\text { D- }[\mathrm{k}] \text { and }[?]\end{array}$ & 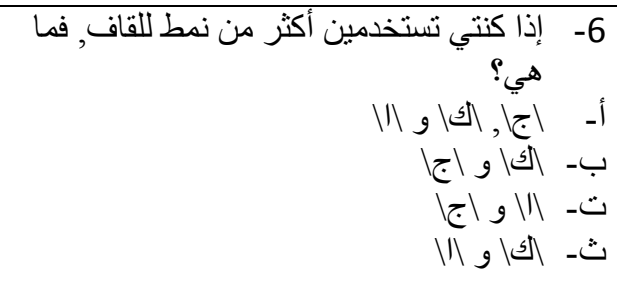 \\
\hline 7- & $\begin{array}{l}\text { How about your family } \\
\text { members, are all of them used } \\
\text { to use variant }[\mathrm{g}],[\mathrm{k}] \text { or }[\mathrm{P}] \text { ? } \\
\text { E- }[\mathrm{g}],[\mathrm{k}] \text { and }[?] \\
\text { F- }[\mathrm{k}] \text { and }[\mathrm{g}] \\
\text { G- }[\mathrm{P}] \text { and }[\mathrm{g}] \\
\mathrm{H}-\quad[\mathrm{k}] \text { and }[?]\end{array}$ & 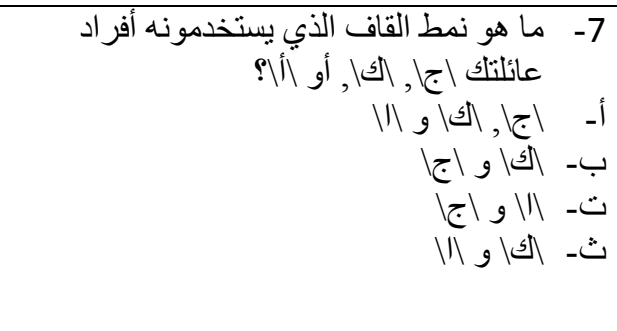 \\
\hline
\end{tabular}

8- If you use different variants, what are the reasons beyond that?

$$
\text { 8- إذا كنتي تستخدمين أكثر من نمط مختلف للقاف, فما هي الأسباب وراء ذلك؟ }
$$

Thank you for your cooperation.

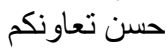

